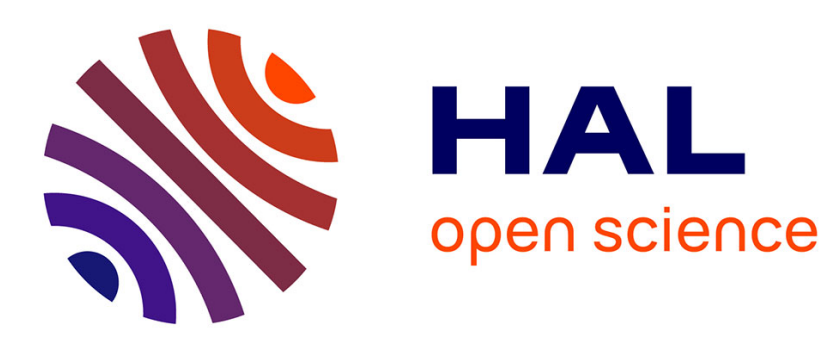

\title{
Polymer Electrolyte Fuel Cell Electrodes Grown by Vapor Deposition Techniques
}

\author{
Pascal Brault, Amaël Caillard, Anne-Lise Thomann
}

\section{To cite this version:}

Pascal Brault, Amaël Caillard, Anne-Lise Thomann. Polymer Electrolyte Fuel Cell Electrodes Grown by Vapor Deposition Techniques. Chemical Vapor Deposition, 2011, 17, pp.296-304. 10.1002/cvde.201100046 . hal-00688827

\section{HAL Id: hal-00688827 https://hal.science/hal-00688827}

Submitted on 18 Apr 2012

HAL is a multi-disciplinary open access archive for the deposit and dissemination of scientific research documents, whether they are published or not. The documents may come from teaching and research institutions in France or abroad, or from public or private research centers.
L'archive ouverte pluridisciplinaire HAL, est destinée au dépôt et à la diffusion de documents scientifiques de niveau recherche, publiés ou non, émanant des établissements d'enseignement et de recherche français ou étrangers, des laboratoires publics ou privés. 
Polymer electrolyte fuel cell electrodes grown by vapor deposition techniques

\author{
Pascal Brault ${ }^{*}$, Amaël Caillard, Anne-Lise Thomann \\ GREMI UMR6606 CNRS-Université d'Orléans BP6744, 45067 ORLEANS Cedex 2, \\ France
}

*Corresponding author: Pascal.Brault@univ-orleans.fr , Tel. +33238417125, Fax $+33238417154$

\begin{abstract}
Polymer fuel cell electrode growth using vapor deposition techniques is reviewed. The supports, the nanocatalyst sizes and morphologies, the resulting electrodes are examined as a function of vapor deposition process: sputtering, CVD, PECVD, MOCVD. In each case, up-to-date fuel cell performances are highlighted. Vapor depositions are valuable techniques for designing fuel cell electrodes of various kinds with good fuel cell performances, e.g. power density and catalyst activity.
\end{abstract}

Keywords: fuel cell, electrode, PVD, CVD, thin film,catalyst, PEMFC 


\section{Introduction}

Low temperature Solid Polymer Fuel Cells, as Proton Exchange Membrane Fuel Cells (PEMFC), Direct alcohol Fuel Cell (DAFC), Solid Alkaline Membrane Fuel Cell (SAMFC) are promising energy power supplies in the context of greenhouse gas reduction. When powered with hydrogen and oxygen, the only by product is warm water. The fuel cell is a direct current source issued from electrochemical conversion of fuel and oxidant (e.g. pure or from air oxygen) at the two electrodes of the fuel cell. These two electrodes are separated by a either proton or anion $\left(\mathrm{OH}^{-}\right)$conducting solid polymer, forming a Membrane-Electrode Assembly (MEA). These electrochemical reactions are summarized in the equation ( 1 and 2$)$ :

Acid fuel cell

Anode half reaction: $\mathrm{H}_{2} \quad \rightarrow 2 \mathrm{H}^{+}+2 \mathrm{e}^{-}(\mathrm{x} 2)$

Cathode half reaction: $\mathrm{O}_{2}+4 \mathrm{e}^{-}+4 \mathrm{H}^{+} \rightarrow 2 \mathrm{H}_{2} \mathrm{O}$

Alkaline fuel cell

Anode half reaction: $\quad 2 \mathrm{H}_{2}+2 \mathrm{OH}^{-} \quad \rightarrow 2 \mathrm{H}_{2} \mathrm{O}+2 \mathrm{e}^{-}(\mathrm{x} 2)$

Cathode half reaction: $\mathrm{O}_{2}+4 \mathrm{e}^{-}+2 \mathrm{H}_{2} \mathrm{O} \rightarrow 4 \mathrm{OH}^{-}$

With the net reaction: $2 \mathrm{H}_{2}+\mathrm{O}_{2} \quad \rightarrow 2 \mathrm{H}_{2} \mathrm{O}$ 
The electrodes are conventionally made of a microporous catalytic layer, a microporous gas diffusion layer (GDL) supported on a carbon backing (carbon cloth or carbon paper). The proton or anion exchange membrane is a polymer allowing ion conduction in wet conditions. These components are fabricated individually and then pressed together at high temperature and high pressure. The interface between the membrane and the electrode is critical ${ }^{[1]}$. The MEA is finally sandwiched by two flow field plates (bipolar plates) for efficient current collection and gas distribution.

Part of the optimization of an electrode design is the attempt to correctly distribute the amount of volume in the catalyst layer between the transport media for each of the three phases (electrons, protons and gases) to reduce transports losses. This catalyst layer is either applied to the membrane or onto the gas diffusion layer. In either case, the objective is to place the catalyst particles (platinum, platinum alloys on non based platinum) in close proximity with the membrane, the carbon particles and the gas fed pores. Designing efficient electrodes remains a challenging tasks for increasing efficiency and stability, ensuring durability (for car application, at least $5000 \mathrm{~h}$ operation is required) and reducing costs (especially due to the noble catalysts).

Many methods are commonly employed to form the microporous catalytic layer ${ }^{[2,3]}$ : chemical synthesis such as colloidal methods (Bönneman ${ }^{[4,5]}$, Water in Oil - Micro emulsion $^{[6]}$, polyol ${ }^{[7,8]}$, carbonyl route ${ }^{[9]}$, impregnation-reduction method ${ }^{[10]}$ and electrochemical impulsion method ${ }^{[11]}$ from salts allows producing supported catalysts ready to be brushed on the GDL. Progresses in GDL manufacturing are also currently 
emerging. Especially, one can mention the use of carbon aerogel, that readily provides new carbon supports for fuel cell electrodes ${ }^{[12-16]}$. Beside these methods, vapor deposition methods are of growing interest for growing the catalyst support (usually carbon based), placing the catalyst nanoclusters on the upper part of the electrode and/or for growing the full electrode as a thin film. The present article will briefly describe current state of the art of these vapor techniques.

\section{New catalyst support materials by vapor depositions}

Chemical Vapor Deposition, in the field of low temperature fuel cell, is mainly used for obtaining nanostructured carbon (possibly porous) thin films as a potential alternative electrocatalyst support to replace traditional carbon black powder materials (i.e. Vulcan ${ }^{\circledast}$ XC72 and Shawinigan ${ }^{\circledR}$ carbon powders). Catalyst coating is further obtained either by salt impregnation (mainly electrodeposition or electroless deposition) or by vapor deposition (mainly plasma sputtering). Two main families of nanostructured carbon supports are obtained by vapor deposition: arrays of carbon nanotubes and nanofibers (CNT/CNF) ${ }^{[17-27]}$ and randomly nanostructured carbon thin films ${ }^{28-33}$. Among the new recent materials, as carbon nanohorns, nanosheets, boron doped diamond or transition metal oxides, this short review will only discuss on transition metal oxides ${ }^{[34,35]}$. 


\subsection{Carbon nanotube and carbon nanofibers}

Carbon nanostructures as nanotubes (single wall or multiwall) - CNT, nanofibers CNF- are expected to provide the essential high surface area to be suitable as catalyst support in a polymer electrolyte fuel cell electrode. In most of the case, nanotubes and nanofibers are grown by catalytic CVD or PECVD. In the latter case, the CNT and CNF are grown at a lower temperature and aligned nanostructures can be easily obtained. Precise growth conditions (precursors, temperature, pressure, flows, ...) depend on reactor geometry, properties of expected CNT, CNF (size, density, vertically aligned or not, ...). Arrays of vertically aligned CNT-CNF are usually grown on macroporous carbon paper or microporous $\mathrm{GDL}^{[22]}$ as shown on Figure 1 and Figure 2, followed by the catalyst impregnation. For simplicity and without loss of generality, we will only discuss on Pt here. The CNF/CNT array is subsequently catalysed by electroless deposition, electrodeposition (by using Pt based salts) and plasma sputtering ${ }^{[23]}$. In the two former cases, all the length of CNT-CNF are decorated by highly dispersed Pt nanoparticles with low degree of agglomeration. Deposition of Pt alloys $\left(\mathrm{Pt}_{\mathrm{x}} \mathrm{Ru}_{\mathrm{y}}, ..\right)$ was also investigated, mainly for methanol DAFC operation. Figure 3 shows the result of two studies where the Pt nanoclusters are mainly located on the top of the CNF/CNT by using plasma sputtering deposition. A Pt concentration and a nanocluster size gradients occur along the CNF/CNT. The agglomeration degree of the Pt particles increases with increasing the Pt loading. The broad range of fuel cell performances and electrocatalytic activities with CNT/ CNF as catalyst supports are strongly dependent on their synthesis methods. The CNT 
supported catalysts show higher resistance to carbon corrosion than the widely used carbon black without sacrificing catalytic activity (an activity enhancement is even observed in some studies). This leads to a lower loss of Pt surface area, to a lower oxygen reduction reaction activity and then improves long term durability. This suggests that (PE)CVD obtained CNT (and CNF) are promising catalyst supports for PEMFC application.

Nitrogen doped carbon nanotubes (NCNT) are also studied as catalyst support ${ }^{[36-38]}$. In most of the case, NCNT are grown by a modified CVD process in a nitrogen rich gas mixture. The Pt nanoparticles deposited by aerosol MOCVD, are uniformly dispersed on the NCNT, have narrower particle size distributions, whereas average Pt particle size is larger with a broader particle size distribution on CNT support as shown on Figure $4 \mathrm{a}$ and $4 \mathrm{~b}$. As a result, the Pt/NCNT electrodes have a greater electrochemical surface area than the Pt/CNT electrodes as well as higher single-cell performance in a $\mathrm{H}_{2} / \mathrm{O}_{2}$ fuel cell as shown on Figure $4 \mathrm{c}$.

Among recent intensive researches in reducing or replacing Pt based electrodes in fuel cells, arrays of boron and/or nitrogen doped CNT without metal have been announced as a good candidate and for the oxygen reduction in alkaline fuel cells ${ }^{[36]}$. Such metal-free materials seem to have interesting electrocatalytic activity, longterm operation stability, and tolerance to crossover effect and to CO presence. 
However, the exact roles of the nitrogen/boron surface species are not clear at the present stage.

Having many similarities to carbon nanotubes (CNTs) in structure and properties, including its high aspect ratio and rich electronic states, graphene is an attractive candidate for potential uses in many areas where the CNTs have been exploited as catalyst support in fuel cell. The synthesis of $\mathrm{N}$ doped graphene sheets by chemical vapor deposition (CVD) is a recent development ${ }^{[39-41]}$ and has been recently exploited for oxygen reduction in fuel cell ${ }^{[39]}$. A free-standing, flexible and transparent film of ca. $4 \mathrm{~cm}^{2}$ in size and consisting of only one or a few layers of the graphite sheets have been synthesized by a CVD process followed by a transfer process. The N-doped graphene film possesses electrocatalytic properties for the oxygen reduction reaction (ORR) similar to that of nitrogen-containing vertically aligned carbon nanotubes.

\subsection{Mesoporous carbon thin film}

Chemical and physical vapor depositions have been recently applied to the synthesis of three dimensional porous carbon thin film matrix to support or to embed $\mathrm{Pt}$ catalyst nanoclusters ${ }^{[28,29]}$. By combining these techniques with another vapor deposition technique, a large range of catalytic layers can be synthesized ${ }^{42}$. Among the various forms of mesoporous carbon thin films, ordered mesoporous carbon (OMC) are of great research interest, especially for electrochemical applications such as fuel cells (lithium ion batteries and capacitor) ${ }^{[30-33]}$. By using a suitable template, such films offer prominent characteristics, such as high surface area, tunable and 
uniform pore size, ordered pore structure, interconnected pore network, tailorable surface properties and good mechanical stabilities. CVD is one of the most used techniques to synthesize such films because of the high degree of pore filling, the formation of graphitic pores walls, the presence of crystallite-sized graphite and the possible absence of dense carbon layer on the external surfaces of the template. The use of OMC leads to higher performance in electrochemical activity than commercial carbon black particle, especially in $\mathrm{DMFC}^{[33]}$. This enhancement is attributed to the uniform mesopore network in $\mathrm{OMC}$ which seems to improve the diffusion of the reactants and the high electrical conductivity of the graphitic OMC.

\subsection{Transition metal oxides}

Transition metal oxides, such as $\mathrm{ZrO}_{2}, \mathrm{SnO}_{2}, \mathrm{RuO}_{2}, \mathrm{TiO}_{2}$, have been applied to improve the durability of the carbon-supported platinum catalysts and the Pt activity for the oxidation reaction of organic molecules (by lowering the adsorption energy of $\mathrm{CO}$ ). It was recently reported that the active surface area of the platinum in the $\mathrm{Pt} / \mathrm{TiO}_{2} / \mathrm{C}$ catalyst was increased with the addition of $\mathrm{TiO}_{2}$ due to the synergy of the interface between $\mathrm{Pt}$ and $\mathrm{TiO}_{2}{ }^{[34]}$. $\mathrm{TiO}_{2}$ thin film has been found to be proton-conducting for thickness below $18 \mathrm{~nm}$ ) and the alcohol permeation of the MEA has been reduced. Very few studies are devoted to vapor deposition of $\mathrm{Pt} / \mathrm{TiO}_{2} / \mathrm{C}$ catalysts. Using $\mathrm{RF}$ magnetron sputtering, Yoo et al ${ }^{[35]}$ have recently synthesized PtRu nanoparticles embedded $\mathrm{TiO}_{2}$ matrix for methanol oxidation with different sizes of PtRu nanoparticles as shown on Figure 5 and indicate that the activities of the methanol 
oxidation reaction are dependent on the PtRu particle size. The high catalytic activity of $\mathrm{PtRu} / \mathrm{TiO}_{2}$ is partially attributed to the effect of the $\mathrm{TiO}_{2}$, on which the hydroxyl $(\mathrm{OH})$ species are absorbed. This causes a shift in the surface oxidation of PtRu which facilitates the removal of $\mathrm{CO}$ from the PtRu nanocatalyst surface and reduces the poisoning of the $\mathrm{Pt}$ in the $\mathrm{PtRu} / \mathrm{TiO}_{2}$ thin film.

\section{Efficient catalyst nanoclusters by vapor depositions}

Two techniques are commonly used to synthesize efficient catalyst nanoclusters for low temperature fuel cell. Plasma sputtering deposition was investigated for its ability to reduce the noble catalyst content in PEMFC electrodes ${ }^{[43-51]}$, in order to reduce fabrication costs while preserving fuel cell performances. Metalorganic CVD (MOCVD) provides an alternative way for depositing efficient catalyst nanoclusters onto gas diffusion layer electrodes ${ }^{[52-56]}$.

The basic principle of plasma sputtering is to sputter a catalyst target with the plasma ions, e.g. argon ${ }^{[43,44]}$. The sputtered atoms are condensing on a substrate located a few centimeters from the target. This substrate can be the gas diffusion layer, or the polymer electrolyte for direct deposition. Plasma sputtering can be readily used for depositing only the catalyst of both the catalyst and the electron conducting matrix (mainly carbon) as described in the next section. Some references give many ways to reduce the catalyst content and eventually to increase the PEM fuel cell efficiency. 
Among them, Cha et $\mathrm{al}^{[45]}$ and then Haug et al $^{[46]}$ have deposited alternate sputtered platinum layers and painted layers of $\mathrm{Nafion}^{\circledR}$ and carbon ink $(\mathrm{NCl})$ directly on the membrane. They have achieved PEMFC performance between 150 and $250 \mathrm{~mW} \mathrm{~cm}{ }^{-2}$ with a cathode Pt loading of about $30-40 \mu \mathrm{g}_{\mathrm{Pt}} \mathrm{cm}^{-2}\left(60-80 \mu \mathrm{g}_{\mathrm{Pt}} \mathrm{cm}^{-2}\right.$ in the entire MEA) using dry (non-humidified) $\mathrm{H}_{2} / \mathrm{O}_{2}$ at 1 atm and $60-70^{\circ} \mathrm{C}$. In the mid $2000^{\prime}$ s, Brault et al have decreased the cathode Pt loading to $20-100 \mu \mathrm{g}_{\mathrm{Pt}} \mathrm{cm}^{-2}$ on the GDL and obtained fuel cell performance of $270 \mathrm{mWcm}^{-2[51]}$ and $400 \mathrm{mWcm}^{-2}{ }^{[43]}$ (with about $100 \mu \mathrm{g}_{\mathrm{Pt}} \mathrm{cm}^{-}$ ${ }^{2}$ ) by using a Nafion ${ }^{\circledR} 115$ and a Nafion ${ }^{\circledR} 112$ membrane, respectively. Considering the efficiency per weight of catalyst, the catalyst utilization efficiency in the plasma prepared cathode reaches $2.7 \mathrm{~kW} \mathrm{~g}_{\mathrm{Pt}}^{-1}$ and $5 \mathrm{~kW} \mathrm{~g}_{\mathrm{Pt}}{ }^{-1}$.

Metalorganic CVD is intended to allow deposition of noble metal catalysts onto gas diffusion layer electrodes rather than using conventional chemical methods ${ }^{[52-56]}$. It is a suitable method for impregnating tortuous electrode supports as shown on Figure 6a. Recent experiments ${ }^{[52]}$ have shown interesting oxidation reduction reaction behavior. For a Pt cathode loading of $100 \mu \mathrm{g}_{\mathrm{Pt}} \mathrm{cm}^{-2}$, the maximum power density, displayed on Figure $6 \mathrm{~b}$, is about $800 \mathrm{~mW} \mathrm{~cm}^{-2}$ in $\mathrm{H}_{2} / \mathrm{O}_{2}$ conditions (4 bars and $80^{\circ} \mathrm{C}$ ) with a Nafion ${ }^{\circledR} 112$ membrane. This leads to a Pt-specific power density of $1.7 \mathrm{kWg}_{\mathrm{Pt}}{ }^{-1}$ (cf Figure 9 in Ref. 52).

\section{Fuel cell electrode thin film growth by vapor co-depositions}


Because of the agglomeration degree of the sputtered Pt particles when increasing the Pt loading, plasma sputtering has been combined with another technique to deposit the catalyst support (mostly carbon) alternately or simultaneously ${ }^{[28,29,50,57-61]}$. Plasma co-sputtering has been used to insert additional metal into the sputtered Pt layer and to modify the seeding and the morphology of Pt deposit ${ }^{[50]}$. The platinum catalyst is more dispersed across the surface and more catalytically active sites are available. By the insertion of $\mathrm{Cr}$ in a $54 \mu \mathrm{g} \cdot \mathrm{cm}^{-2} \mathrm{Pt}$ loaded electrode, Gruber et al. improved the fuel cell performance to $200 \mathrm{~mW} \cdot \mathrm{cm}^{-2}$ (in a $\mathrm{H}_{2} / \mathrm{O}_{2}$ cell at room temperature and ambient pressure with a Nafion ${ }^{\circledR} 115$ membrane), corresponding to the maximum power density gained at twice the Pt loading alone.

Using Pt-C co-sputtering on commercial carbon $\mathrm{GDL}^{[58]}$, highest efficient use of catalyst has been reached very recently due to efficient ultra low Pt loading (10 $\mu \mathrm{g}_{\mathrm{Pt}} \cdot \mathrm{cm}^{-2}$ at both anode and cathode) : $20 \mathrm{~kW} \cdot \mathrm{g}_{\mathrm{Pt}}{ }^{-1}$ (Figure 7). This result has been obtained with a Nafion ${ }^{\circledR} 112$ membrane and in a $\mathrm{H}_{2} / \mathrm{O}_{2}$ cell at $80^{\circ} \mathrm{C}$ and 3 bars. The main advantage in the successful use of plasma co-sputtering deposition techniques is to locate a very low catalyst quantity, with the correct density profile at the interface membrane-electrode: so the triple boundary point is very effective. High level performance with low Pt contents means, especially at the cathode side, that all the Pt atoms are involved in the electrochemical fuel cell reactions. Moreover, the Pt nanoclusters size distribution is very narrow and mean average size can be very low at low loading: $0.7 \mathrm{~nm}$ to $2 \mathrm{~nm}$. 
Electrocatalytic hydrocarbon thin films containing Pt nano-clusters are deposited by simultaneous plasma polymerization of ethylene in a PECVD reactor and simultaneous sputtering of a Pt target $t^{[59,60]}$ in the same reactor drawn in figure $8 \mathrm{a}$. The proposed approach is largely intended to propose an alternative PEMFC electrode (anode) fabrication method. The deposition of the carbon matrix provides the mechanical support and electronic continuity due to sufficient conduction properties. It ensures a uniform metal dispersion. The Pt catalyst is dispersed as small vertically stacked clusters with size less than $10 \mathrm{~nm}$ around hydrocarbon columns (250-500 nm height) of the films. PEMFC tests with plasma deposited $500 \mathrm{~nm}$ thick film and $0.5 \mathrm{mg} \mathrm{cm}^{-2} \mathrm{Pt}$ loading as anodic electrocatalyst leads to a power density of $300 \mathrm{~mW} \mathrm{~cm}^{-2}$. PECVD and plasma sputtering can also operate successively. Caillard et $\mathrm{al}^{[61]}$ have successfully sputtered platinum nanoclusters $\left(10-100 \mu \mathrm{g} / \mathrm{cm}^{2}\right)$ on a array of vertically aligned $2 \mu \mathrm{m}$ long carbon nanofibers previously grown by Helicon plasma enhanced CVD. The presence of such plasma obtained aligned carbon structures displayed on Figure $8 \mathrm{~b}$ increases the fuel cell performance from $15 \%$ to $30 \%$ for a $\mathrm{Pt}$ loading in the range $10-100 \mu \mathrm{g}_{\mathrm{Pt}} \mathrm{cm}^{-2}$.

\section{Conclusion}

This short review is aiming to present both CVD and plasma sputtering deposition techniques in the field of improvement of fuel cell electrodes as an alternative to conventional or original chemical impregnation method. All the presented methods are successfully used to build efficient fuel cells electrodes. Plasma sputtering technique is combining the advantages for depositing pure catalyst and/or carbon atoms without any additional bonds lowering the catalytic activity. It is also advantageous for controlling catalyst distribution near the electrolyte polymer 
membrane and the mean size distribution. So high fuel efficiency, $20 \mathrm{kWg}_{\mathrm{Pt}}{ }^{-1}$ has been recorded.

\section{Acknowledgements}

We are indebted to C. Coutanceau, C. Lamy, R. Boswell and C. Charles for highlighting discussions and strong encouragements. GDR PACEM, PACS, PACTE and PIE CNRS are warmly acknowledged for continuous support. 


\section{References.}

[1] S. Litster, G. McLean, J. Power Sources 2004, 130, 61.

[2] A. Chen, P. Holt-Hindle, Chem. Rev. 2010, 110, 3767.

[3] Fuel Cell Catalysis (Ed. M. T. Koper), Wiley, Hoboken NJ, 2009.

[4] R. Sellin, C. Grolleau, C. Coutanceau, J.-M. Leger, S. Arrii-Clacens, S. Pronier, J.-M. Clacens, J. Phys. Chem. C 2009, 113, 21735.

[5] L. Dubau, F. Hahn, C. Coutanceau, J. -M. Léger, C. Lamy, J. Electroanal. Chem. 2003, 554-555, 407.

[6] S. Brimaud, C. Coutanceau, E. Garnier, J.-M. Léger, F. Gérard, S. Pronier, M. Leoni, J. Electroanal. Chem. 2007, 602, 226.

[7] C. Grolleau, C. Coutanceau, F. Pierre, J.M. Leger, J. Power Sources 2010, 1951569.

[8] E. Lebègue, S. Baranton, C. Coutanceau, J. Power Sources 2011, 196, 920.

[9] H. Yang, C. Coutanceau, J.-M. Léger, N. Alonso-Vante, C. Lamy J. Electroanal. Chem. 2005, 576, 305.

[10] F. Vigier, C. Coutanceau, A Perrard, E. M. Belgsir, C. Lamy, J. Appl. Electrochem., $200434,439$.

[11] C. Coutanceau, A. Rakotondrainibe, A. Lima, E. Garnier, S. Pronier, J. M. Léger, C. Lamy, J. Appl. Electrochem. 2004, 34, 61.

[12] J. Marie, R. Chenitz, M. Chatenet, S. Berthon-Fabrya, N. Cornet, P. Achard, J. Power Sources 2009, 190, 423-434

[13] J. Marie, S. Berthon-Fabry, P. Achard, M. Chatenet, A. Pradourat, E. Chainet, J. Non-Crystalline Solids 2004, 350, 88-96 
[14] C. D. Saquing, T.-T. Cheng, M. Aindow, C. Erkey, J. Phys. Chem. B 2004, 108, 77167722

[15] M. Glora, M. Wiener, R. Petricevic, H. Probstle, J. Fricke, J. of Non-Crystalline Solids 2004, 285, 283-287

[16] J. Marie, S. Berthon-Fabry, M. Chatenet, E. Chainet, R. Pirard, N. Cornet, P. Achard, J. Appl. Electrochem. 2007, 37, 147-153

[17] K. Lee, J. Zhang, H. Wang, D. P. Wilkinson, J. Appl. Electrochem. 2006, 36, 507 (Reviews in Applied Electrochemistry Number 60)

[18] C. Wang, M. Waje, X. Wang, J. M. Tang, R. C. Haddon, Y. Yan, Nano Lett. 2004, 4, 345

[19] X. Wang, M. Waje, Y. Yan, Electrochem. Solid-State Lett. 2005, 8, A42

[20] M. M Waje, X. Wang, W. Li and Y. Yan, Nanotechnology 2005, 16, S395-S400

[21] M. Sudan Saha, R. Li, X. Sun, S. Ye, Electrochem. Comm. 2009, 11, 438

[22] A. Caillard, C. Charles, R. Boswell , P. Brault, Ch. Coutanceau, Appl. Phys. Lett. 2007, 90, 223119

[23] A. Caillard, C. Charles, R. Boswell, P. Brault, J. Phys. D 2008, 48, 185307

[24] Y. Shao, G. Yin, Y. Gao, and P. Shi, J. Electrochem. Soc. 2006, 153, A1093

[25] Z. Tang, C. K. Poh, K. K. Lee, Z. Tian, D.H.C. Chua, J. Lin, J. Power Sources 2010, 195, 155.

[26] J.M. Tang, K. Jensen, M. Waje, W. Li, P. Larsen, K. Pauley, Z. Chen, P. Ramesh, M.E. Itkis, Y. Yan, R. C. Haddon, J. Phys. Chem. C 2007, 111, 17901-17904 
[27] F. Alcaide, G. Álvarez, O. Miguel, M.J. Lázaro, R. Moliner, A. López-Cudero, J.

Solla-Gullón, E. Herrero, A. Aldaz, Electrochem. Comm. 2009, 11, 1081-1084

[28] H. Rabat, P. Brault, Fuel Cells 2008, 8, 81

[29] H. Rabat, C. Andreazza, P. Brault, A. Caillard, F. Béguin, C. Charles, R. Boswell, Carbon 2009, 47, 209

[30] A. Zakhidov, R. H. Baughman, Z. Iqbal, C. Cui, I. Khayrullin, S. O. Dantas, J. Marti, V. G. Ralchenko, Science 1998, 282, 897

[31] J. Lee, J. Kim, T. Hyeon, Adv. Mater. 2006, 18, 2073

[32] K.-Y. Chan, J. Ding, J. Ren, S. Cheng, K.Y. Tsang, J . Mater. Chem., 2004, 14, 505516

[33] F. Su, J. Zeng, X. Bao, Y. Yu, J.Y. Lee, X. S. Zhao, Chem. Mater. 2005, 17, 39603967

[34] H. Ekström, B. Wickman, M. Gustavsson, P. Hanarp, L. Eurenius, E. Olsson, G. Lindbergh, Electrochimica Acta 2007, 52, 4239.

[35] S. J. Yoo, T.-Y. Jeon, Y.-H. Cho, K.-S. Lee, Y.-E. Sung, Electrochimica Acta 2010, 55, 7939-7944

[36] K. Gong, F. Du, Z. Xia, M. Durstock, L. Dai, Science 2008, 323, 760

[37] Y. Shao, J. Sui, G. Yin, Y. Gao, Applied Catalysis B: Environmental 2008, 79, 89

[38] Y. Liu, J. Chen, W. Zhang, Z. Ma, G. F. Swiegers, C. O. Too, G. G. Wallace, Chem. Mater. 2008, 20, 2603-2605

[39] L. Qu, Y. Liu, J.-B. Baek, L. Dai, Nano 2010, 4, 1321

[40] K.S. Kim, Y. Zhao, H. Jang, S.Y. Lee, J.M. Kim, K.S. Kim, J.H. Ahn, P. Kim, J.Y. Choi, B.H. Hong, Nature 2009, 457, 706-710. 
[41] A. Reina, X. Jia, J. Ho, D. Nezich, H. Son, V. Bulovic, M.S. Dresselhaus, J. Kong, Nano Lett. 2009, 9, 30-35

[42] P. Brault, Surf. Coat. Technol. 2011, doi:10.1016/j.surfcoat.2011.01.052

[43] P. Brault, A. Caillard, A. L. Thomann, J. Mathias, C. Charles, R. W. Boswell, S. Escribano, J. Durand, T. Sauvage, J. Phys. D 2004, 37, 3419-3423

[44] P. Brault, S. Roualdès, A. Caillard, A.L. Thomann, J. Mathias, J. Durand, Ch. Coutanceau, J.M. Léger, C. Charles, Rod Boswell, Eur. Phys. J. Applied Phys. 2006, 34, 151-156

[45] S.Y. Cha, W.M. Lee, J. Electrochem. Soc. 1999, 146, 4055 ()

[46] S. Hirano, J. Kim, S. Srinivasan, Electrochim. Acta 1997, 42, 1587

[47] S. Mukerjee, S. Srinivasan, A.J. Appleby, Electrochim. Acta 1993, 38, 1661

[48] R. O’Hayre, S.J. Lee, S.W. Cha, F.B. Prinz, J. Power Sources 2002, 109, 483

[49] A.T. Haug, R.E. White, J.W. Weidner, W. Huang, S. Shi, T. Stoner, N. Rana, J. Electrochem. Soc. 2002, 149, A280

[50] D. Gruber, N. Ponath, J. Müller, F. Lindstaedt, J. Power Sources 2005, 150, 67-72

[51] A. Caillard, C. Charles, R. Boswell, P. Brault, J. Phys. D: Appl. Phys. 2005, 42, 045207

[52] E. Billy, F. Maillard, A. Morin, L. Guetaz, F. Emieux, C. Thurier, P. Doppelt, S. Donet, S. Mailley, J. Power Sources 2010, 195, 2737-2746

[53] M.A. Garcia-Contreras, S.M. Fernandez-Valverde, J.R. Vargas-Garcia, J. Alloys and Compounds 2010, 504S, S425-S428 
[54] P. Fugier, S. Passot, C. Anglade, L. Guetaz, N. Guillet, E. De Vito, S. Mailley, and A.

A. Franco, J. Electrochem. Soc. 2010, 157, B943-B951

[55] H. Kim, S. H. Moon, Carbon 2011, 49, 1491-1501

[56] W. Zhang, M. K. S. Li, P.-L. Yue, P. Gao, Langmuir 2008, 24, 2663-2670

[57] N. Soin, S.S. Roy, L. Karlsson, J.A. McLaughlin, Diamond \& Related Materials 2010, 19, 595.

[58] K. Prehn, R. Adelung, M. Heinen, S. P. Nunes, K. Schulte, J. Membrane Science 2008, 321, 123-130

[58] M. Cavarroc, A. Ennadjaoui, M. Mougenot, P. Brault, R. Escalier, Y. Tessier, J. Durand, S. Roualdès, T. Sauvage, C. Coutanceau, Electrochem. Comm. 2009, 11, 859861

[59] E. Dilonardo, A. Milella, F. Palumbo, G. Capitani, R. d’Agostino, F. Fracassi, Plasma Process. Polym. 2010, 7, 51-58

[60] E. Dilonardo, A. Milella, F. Palumbo, J. Thery, S. Martin, G. Barucca, P. Mengucci, R. d'Agostino, F. Fracassi, J. Mater. Chem., 2010, 20, 10224-10227

[61] A. Caillard, C. Charles, R. Boswell, P. Brault, Nanotechnology 2007, 18, 305603 


\section{Figure captions}

\section{Figure 1:}

(a) SEM images of $2 \mu \mathrm{m}$ long aligned CNF grown a $5 \mu \mathrm{m}$ in diameter carbon fiber by PECVD with a close up showing a side view of the CNF array (reproduced from [22]);

(b) SEM images of $1 \mu \mathrm{m}$ long CNF grown on a microporous GDL with a close up showing the top view of the CNF array (reproduced from [22]);

(c) Cell voltage E versus current density j curves and power density P versus current density $\mathrm{j}$ in a single $5 \mathrm{~cm}^{2}$ surface area PEMFC with different Pt/C cathode structures : $\left(-\triangle_{-}\right)$cathode without GDL and with CNF , (- $\square$ ) cathode with CNF and diffusion layer and (-๑-) cathode without CNF and with diffusion layer (reproduced from [22]). MEA assembly: Cathode sputtered Pt loading: $20 \mu \mathrm{g}_{\mathrm{Pt}} \mathrm{cm}^{-2}$, Commercial anode Pt loading $500 \mathrm{\mu g}_{\mathrm{Pt}} \mathrm{cm}^{-2}$, Untreated Nafion ${ }^{\circledR} 115$ membrane, hot-pressed MEA $\left(130{ }^{\circ} \mathrm{C}\right.$ for $120 \mathrm{~s}$ under a pressure of $40 \mathrm{~kg} \mathrm{~cm}^{-2}$ ). Operating conditions: cell temperature $80^{\circ} \mathrm{C}$, $\mathrm{H}_{2} / \mathrm{O}_{2}$ back pressure 3 atm.

\section{Figure 2:}

(a) SEM images of CNTs deposited directly on carbon paper by CVD (reproduced from [20]);

(b) In situ CVs of CNT-based electrode and conventional electrode at a scan rate of 50 $\mathrm{mV} \mathrm{s}^{-1}$ by supplying $\mathrm{N}_{2}$ to the cathode side (serving as working electrode) and $\mathrm{H}_{2}$ to the anode side (serving as counter and reference electrode) (reproduced from [19]); 
(c) Cell voltage E versus current density j curves and power density P versus current density in a single PEMFC cell for (- $\square$ ) CNT-based electrode, (-๑-) conventional electrode, and ( $\left.-\Delta_{-}\right)$CNT-based electrode without diffusion layer (Reproduced from [(Reproduced from [19]). MEA assembly : Nafion ${ }^{\circledR} 115$ membrane, hot pressed MEA at $135^{\circ} \mathrm{C}$, under $140 \mathrm{~atm}$ for $90 \mathrm{~s}$. Pt loading for the commercial electrodes and CNTbased electrodes: $0.15 \mathrm{mg} \mathrm{cm}{ }^{-2}$. Operating conditions: cell temperature $70^{\circ} \mathrm{C}, \mathrm{H}_{2} / \mathrm{O}_{2}$ back pressure 3 atm.

\section{Figure 3:}

(a) HRTEM Images of the upper end of a PECVD obtained CNF surrounded by PVD obtained Pt nanoparticles with 4 close ups of Pt nanoclusters along the CNF (reproduced from [61]). Synthesis conditions: RF power of $500 \mathrm{~W}, \mathrm{CH}_{4} / \mathrm{H}_{2}$ gas mixture, pressure: $0.5 \mathrm{~Pa}$, substrate temperature: $400{ }^{\circ} \mathrm{C}$, substrate bias: $-100 \mathrm{~V}$, deposition time: $90 \mathrm{~min}$. Pt loading of $0.02 \mathrm{mg}_{\mathrm{Pt}} \mathrm{cm}^{-2}$ deposited by plasma sputtering. (b) HRTEM images of $20 \mu \mathrm{m}$ long and $60-80 \mathrm{~nm}$ in diameter VACNT obtained by microwave-PECVD and covered by sputtered Pt nanoparticles : (A) CNT tip, (B) inset showing individual nanoparticles on base of CNTs, (C) individual nanoparticles along the middle length of CNT (reproduced from [57]). Synthesis conditions: microwave power of $450 \mathrm{~W}$ using a $\mathrm{CH}_{4} / \mathrm{N}_{2}$ mixture at a substrate temperature of $1000{ }^{\circ} \mathrm{C}$, Pt loading of $21 \mu \mathrm{g}_{\mathrm{Pt}} \mathrm{cm}^{-2}$ deposited by DC sputtering. 


\section{Figure 4:}

TEM images of (a) regular CNTs and (b) CNx grown on carbon paper using a aerosolassisted chemical vapor deposition (AA-CVD) method and after deposition of $\mathrm{Pt}$ nanoparticles by the impregnation method. Insets: size distribution of Pt particles (reproduced from [21]). Synthesis conditions: gas mixture: ferrocene/mxylene/argon $/ \mathrm{H}_{2}$, temperature : $850^{\circ} \mathrm{C}$. For the growth of $\mathrm{CN}_{\mathrm{x}}$, the metal catalyst precursor, $1.1 \mathrm{mM}$ [Fe(III)(acetylacetonate)3], is dissolved in a mixture of acetonitrile and tetrahydrofuran.

(c) Comparison of cell performance with MEAs made of $\mathrm{Pt} / \mathrm{CNT}, \mathrm{Pt} / \mathrm{CNx}$ and conventional Pt/C electrodes. Operating conditions: $\mathrm{H}_{2} / \mathrm{O}_{2}$ at $80^{\circ} \mathrm{C}$, Nafion ${ }^{\circledast} 112$ membrane, 25/30 psig anode and cathode back pressure, respectively. Anodes were commercial electrodes with a Pt loading of $0.5 \mathrm{mgcm}^{-2}$ (reproduced from [21]). The Pt loading in the Pt/CNTs and Pt/CN based cathode were determined to be 0.11 and $0.12 \mathrm{mgcm}^{-2}$, respectively.

\section{Figure 5:}

Mean particle size of the PtRu nanoparticles in the $\mathrm{TiO}_{2}$ matrix as a function of the ratio of the $\mathrm{TiO}_{2}$ magnetron power to PtRu magnetron power and HR-TEM images of the PtRu/ $\mathrm{TiO}_{2}$ nanocatalysts with PtRu particle sizes of (a) $1.8 \mathrm{~nm}$, (b) $2.3 \mathrm{~nm}$, and (c) $3.7 \mathrm{~nm}$ (reproduced from [35]). 


\section{Figure 6:}

Cross-sections of carbon particles covered by Pt nanoparticles obtained by direct liquid injection metal organic chemical vapor deposition (DLI-MOCVD) observed by TEM at different distances from the interface with the PEM. (a) Interface $0 \mu \mathrm{m}$, (b) $2.5 \mu \mathrm{m}$, (c) $6 \mu \mathrm{m}$. Synthesis conditions : Commercial Organo-metallic precursors (dimethyl 1,5-cyclooctadiene platinum) solubilized in toluene (Aldrich) is injected with nitrogen at high pressure in the chamber. The solvent is evaporated or decomposed by thermal effect and oxidative atmosphere. Depositions were made under oxidative atmosphere $\left(\mathrm{O}_{2}\right)$, at $320^{\circ} \mathrm{C}$ bars (reproduced from [52]).

(d) Maximal power density (squares), power density at $1 \mathrm{Acm}^{-2}$ (circles) and power density at $0.5 \mathrm{Acm}^{-2}$ (triangles) as a function of the cathode Pt loading. Operating conditions: Nafion ${ }^{\circledR} 112$ membrane, $80^{\circ} \mathrm{C}, \mathrm{H}_{2} / \mathrm{O}_{2}$ conditions, backpressure of 4 bars (reproduced from [52]). Synthesis conditions: same procedure with a home-made precursor, Depositions at $250 \circ \mathrm{C}$

\section{Figure 7:}

(a) TEM view of scratched PtC nanocolumns (Pt loading of $10 \mu \mathrm{g}_{\mathrm{Pt}} \mathrm{cm}^{-2}$ ) deposited by planar inductively coupled plasma sputtering. The Pt nanoclusters are seen as the darker region. 
(b) Cell voltage E versus current density j curves and power density P versus current density in a single PEMFC cell using electrodes catalyzed by plasma sputtering (loading of $2 \times 10 \mu \mathrm{g}_{\mathrm{Pt}} \mathrm{cm}^{-2}$ ). MEA assembly : Nafion ${ }^{\circledR} 212$ membrane, without hot pressing. Operating conditions: cell temperature $80^{\circ} \mathrm{C}, \mathrm{H}_{2} / \mathrm{O}_{2}$ backpressure of $3.1 / 3.8$ atm (reproduced from [58]).

(c) Transmission electron Microscopy Pt nanoclusters decorated carbon grain leading to performance in (b)

\section{Figure 8:}

(a) Schematic of the plasma reactor combining PECVD process and PVD process used to synthesize $\mathrm{Pt} / \mathrm{CH}_{\mathrm{x}}$ thin film, low magnification TEM images of the $\mathrm{Pt} / \mathrm{CH}_{\mathrm{x}}$ thin film containing $60 \%$ of Pt and high resolution images (reproduced from [59]).

(b) Schematic of the plasma reactor combining PECVD process and PVD process used to synthesize Pt/ACNF thin film, SEM images of the Pt/ACNF thin film (Pt loading of 20 $\mu \mathrm{g}_{\mathrm{Pt}} \mathrm{cm}^{-2}$ ) and ACNF tip (inset) (reproduced from [61]). 

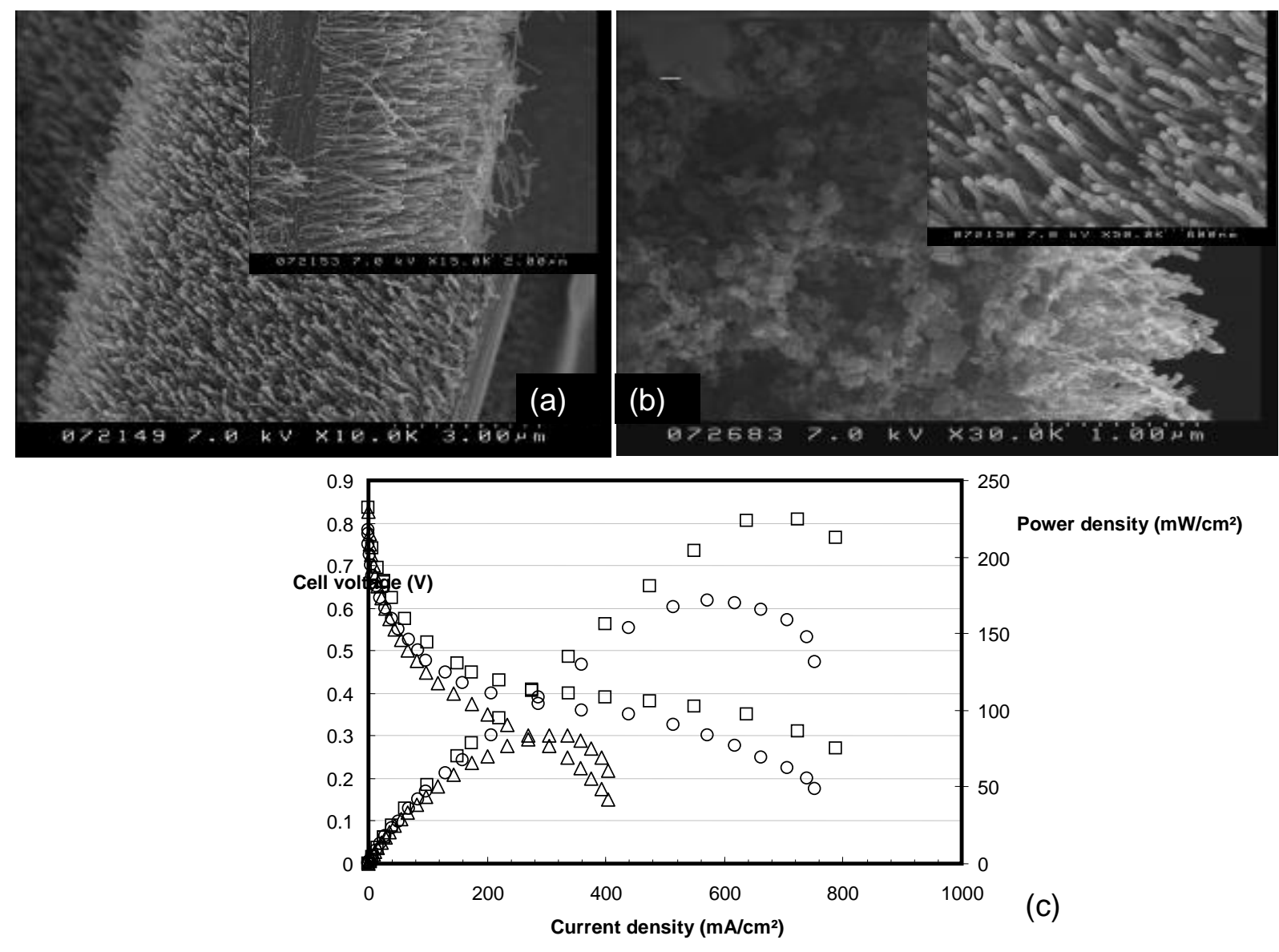

Fig. 1 


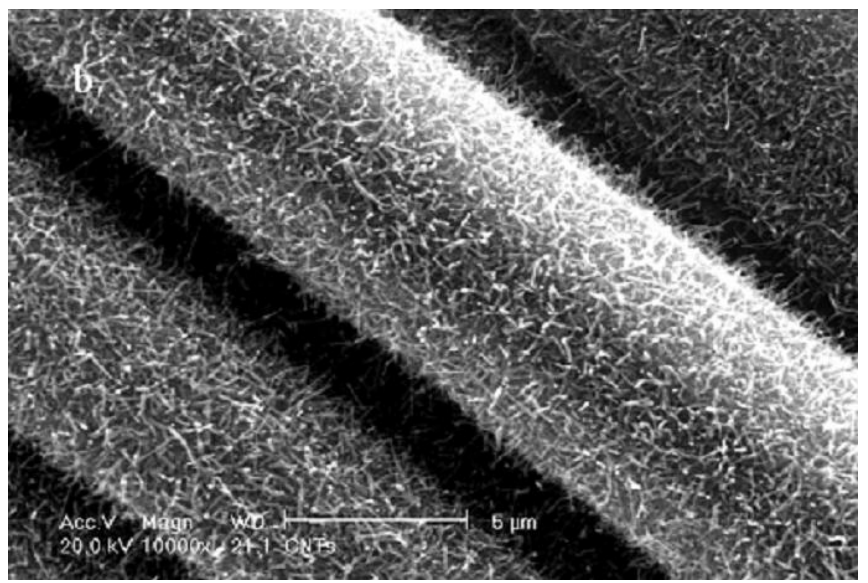

(a)
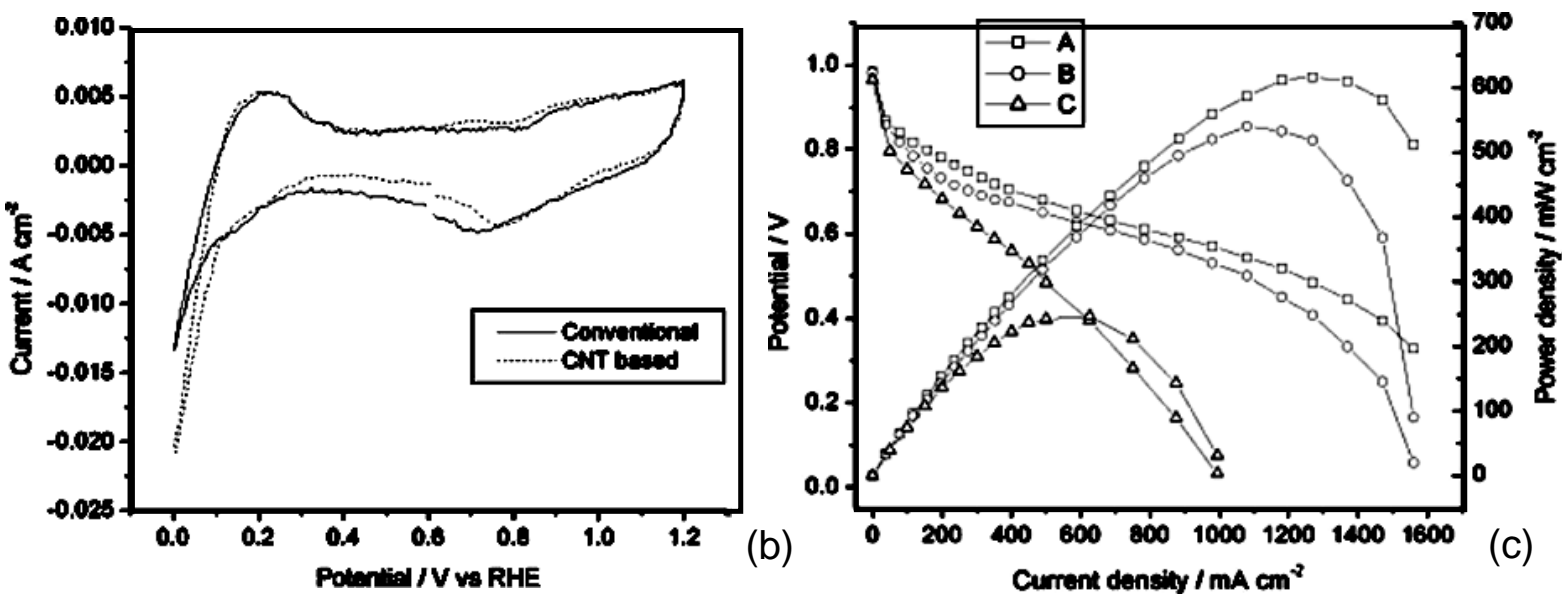

Fig. 2 


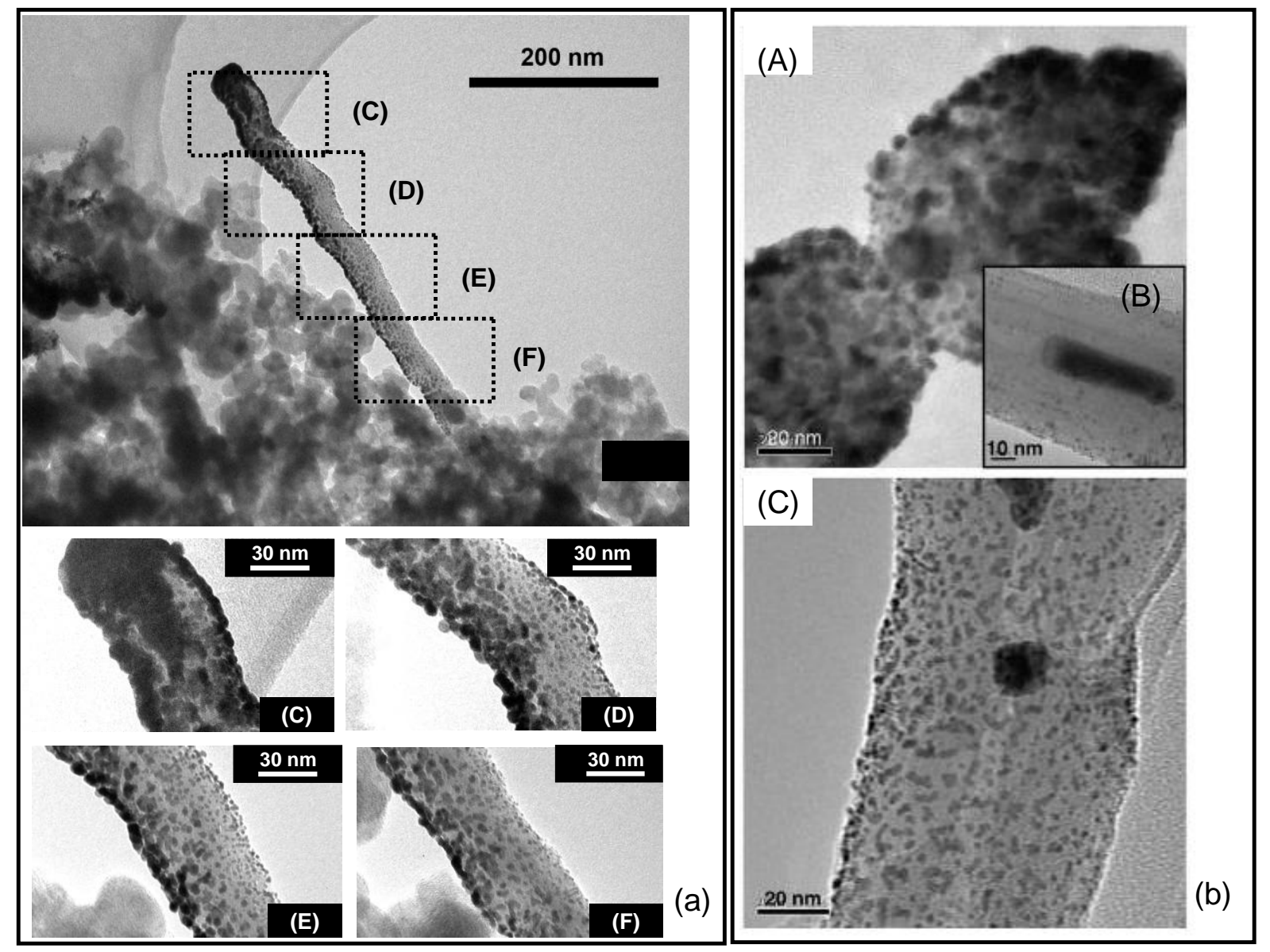

Fig. 3 


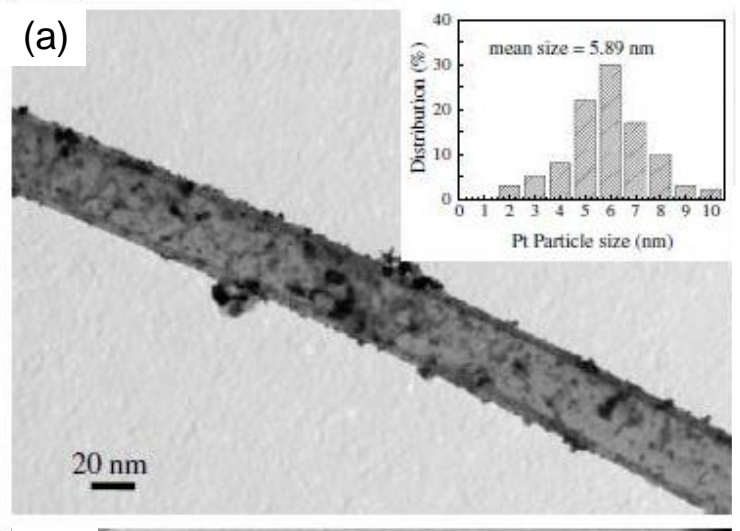

(b)

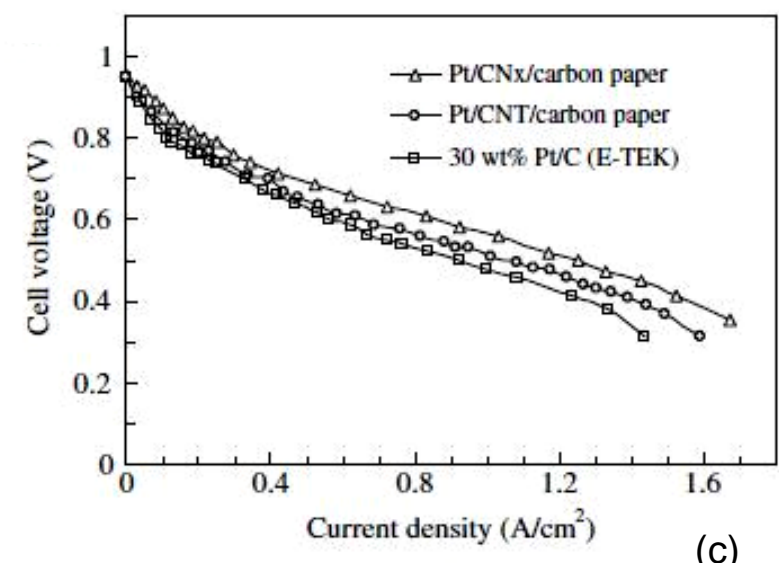

Fig. 4 


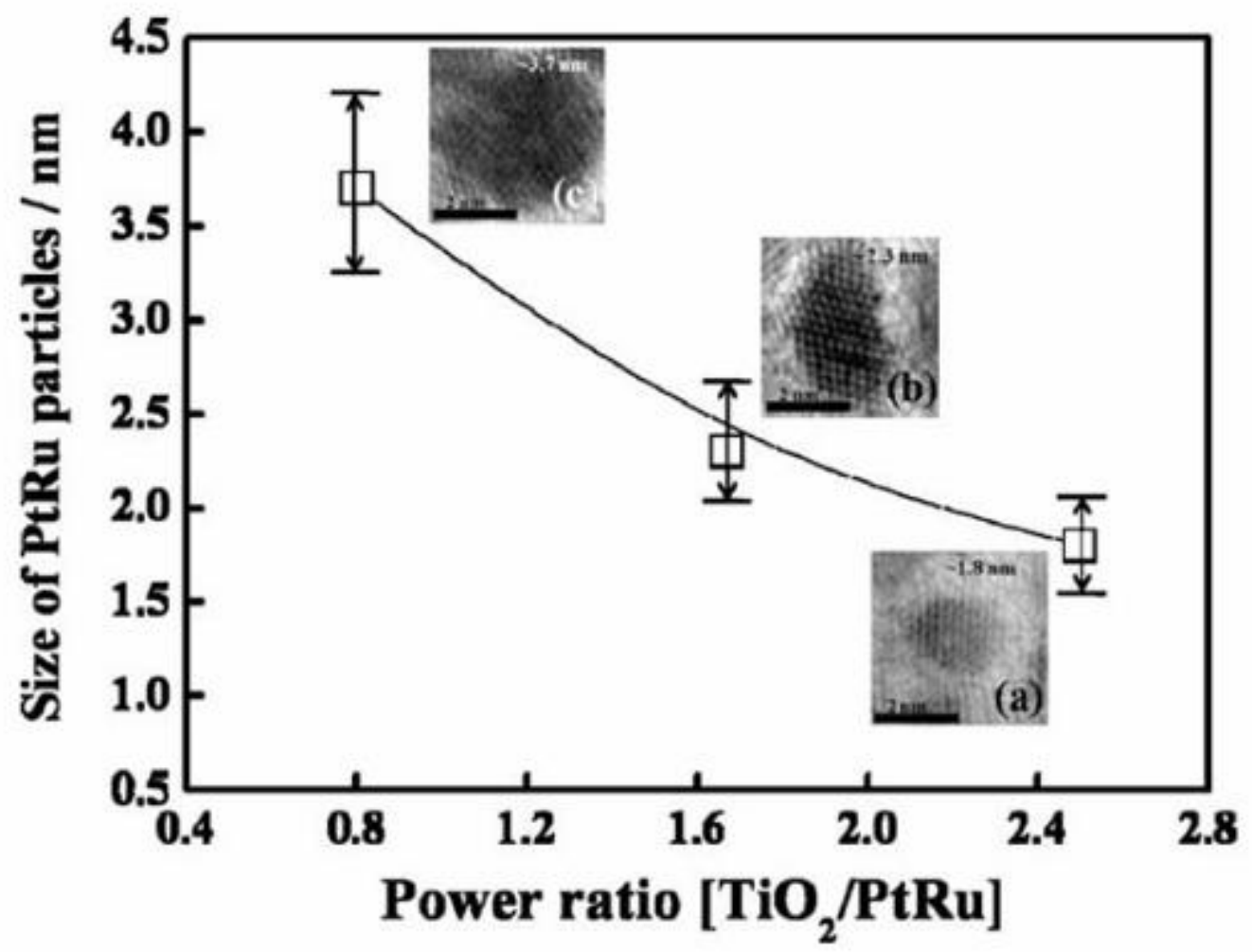

Fig. 5 


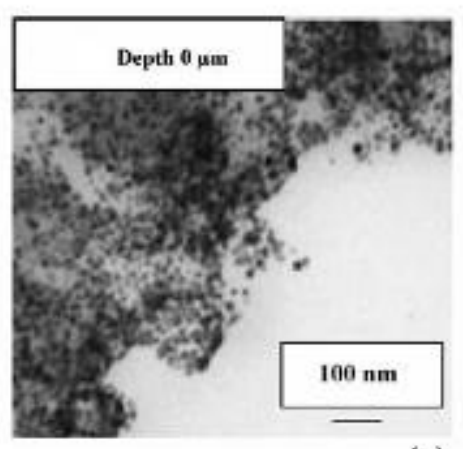

(a)

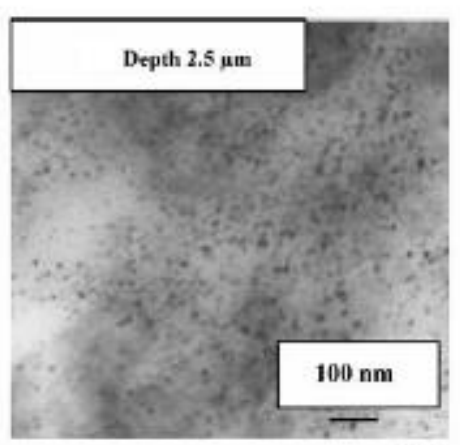

(b)

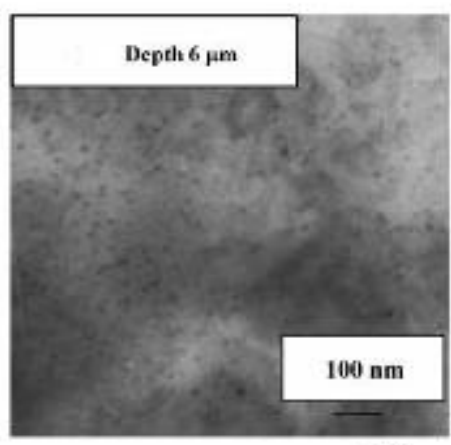

(c)

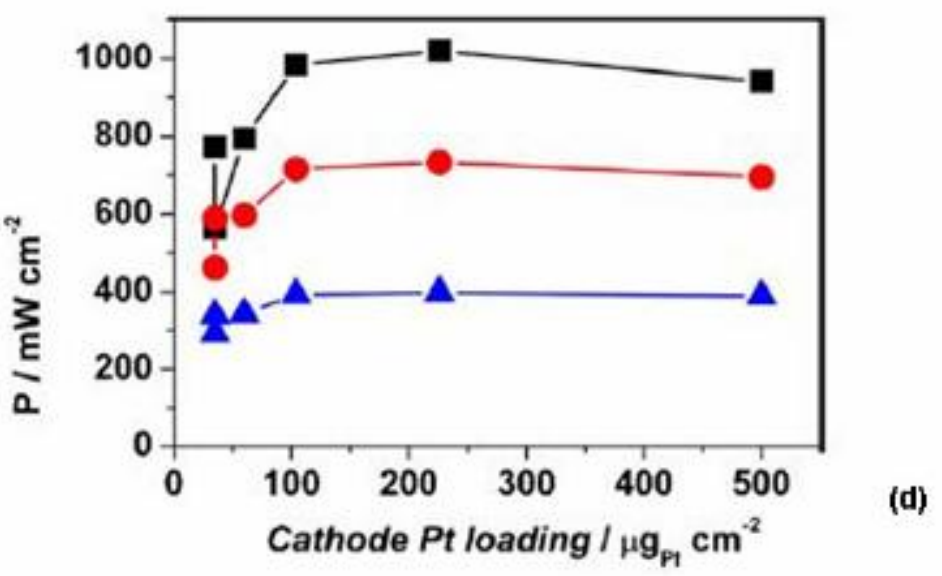

Fig. 6 


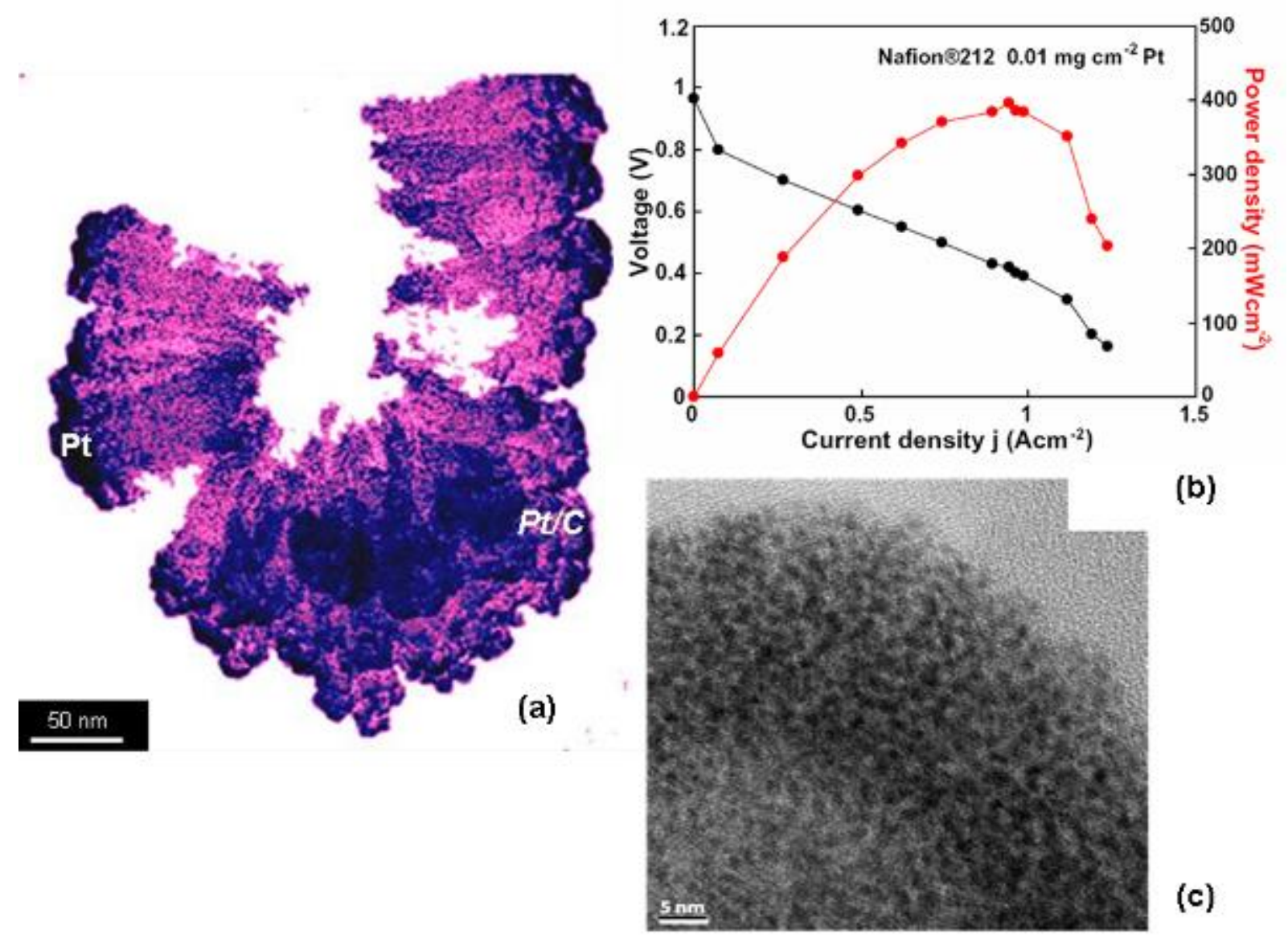

Fig. 7 


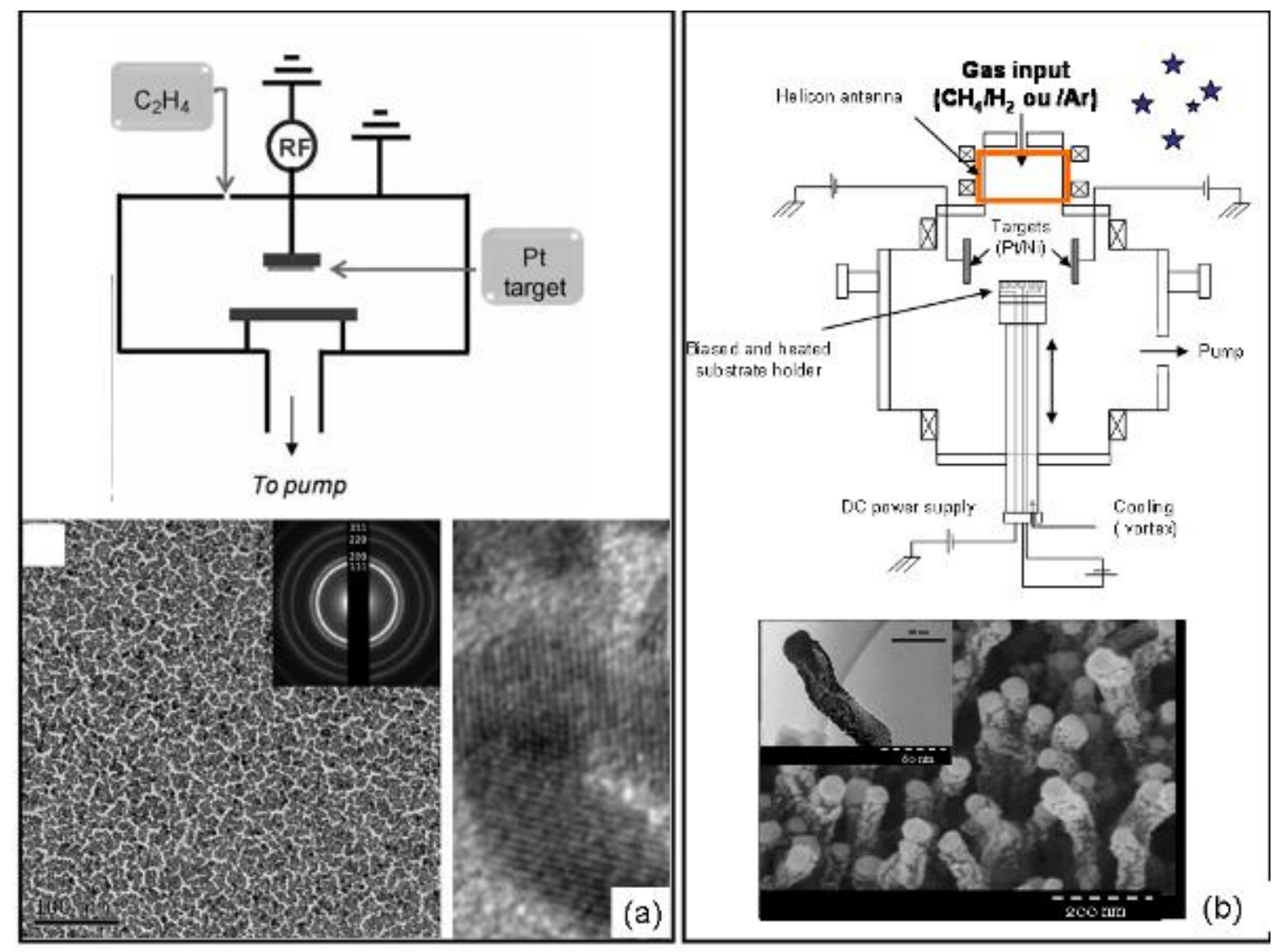

Fig. 8 